\title{
Manajemen Kecerdasan Spiritual Dalam Menyikapi Paham Radikalisme Di Indonesia
}

Oleh:

Armansyahfudin

Email: armansyahfudin0@gmail.com

\begin{abstract}
Abstrak
Manajemen merupakan ilmu untuk mengatur atau mempengaruhi orang lain untuk mencapai tujuan yang telah ditetapkan. Manajemen yang baik akan menciptakan perubahan yang besar terhadap usaha yang dilakukan, kondisi sosial, dan juga peruabahn terhadap diri pribadi. Manajemen yang baik terhadap diri akan meningkat kecerdasan yang dimiliki. Salah satunya kecerdasan spiritual. Kecerdasan spiritual merupakan upaya mengarahkan setiap perbuatan yang dilakukan untuk selalu mengikuti kemampuan pribadinya yang mempunyai keahlian transenden, serta kesadaran yang besar untuk melewati kehidupan dengan menggunakan pengetahuan spiritual untuk mencari jalan keluar tentang permasalahan hidup. Salah satu permasalahan hidup yang berkembang di masyarakat adalah beredarnya paham-paham yang ekstrim dan bersifat negatif. Salah satunya paham radikalisme. Radikalisme di indonesia sudah berkembang sejak penjajahan belanda, dan semakin subur setelah jatuhnya rezim orde baru. Suburnya paham radikalisme di indonesia di pengaruhi oleh kurangnya kesadaran spiritual yang dimiliki. Akibatnya doktrin-doktrin mudah masuk, salah satunya doktrin yaitu jihad. Selanjutnya radikalisme dipengaruhi oleh globalisasi dan pendidikan,. Efek dari paham radikalisme ini menimbulkan keresahan di masyarakat. Untuk itu diperlukan upaya yang serius dalam menyikapi paham radikalisme ini, baik dari pemerintah, ilmuwan dan masyarakat pada umumnya. Oleh karenanya di perlukan manajemen yang efektif untuk menyikapi radikalisme yang marak berkembang di masyarakat. Salah satunya manajemen kecerdasan spiritual. Proses membangun manajemen kecerdasan spiritual ini bisa dilakukan dengan cara memberikan bimbingan, seperti mengajarkan al-Qur'an, melatih pelaksanaan shalat, melatih berpuasa, melatih pelaksanaan haji dan memanfaatkan metode dakwah Rasulullah s.a.w yaitu metode pendekatan keteladanan, memaksimalkan pemanfaatan waktu, sikap adil, mendoakan kebaikan, mengaktifkan potensi berpikir dan mengembangkan mental. Selanjutnya dalam pendidikan dengan memberikan pendidikan akhlak, yang meliputi pembiasaan, pemahaman tentang yang mana perbuatan baik dan buruk, penugasan-penugasan yang didalamnya terdapat teguran, pembersihan bathin atau jiwa dari semua perbuatan yang jahat dan hina, serta sanggung untuk hidup berakhlak.
\end{abstract}

Kata kunci: Manajemen, Kecerdasan Spiritual, Radikalisme 


\begin{abstract}
Management is the science of regulating or influencing others to achieve the stated goals. Good management will create a great change in the business carried out, social conditions, and also personal changes. Good management of self will increase the intelligence possessed. One of them is spiritual intelligence. Spiritual intelligence is an effort to direct every action taken to always follow his personal abilities that have transcendent skills, as well as a great awareness to pass through life by using spiritual knowledge to find a way out about life's problems. One of the problems of life that develops in society is the circulation of extreme and negative understandings. One of them is radicalism. Radicalism in Indonesia has developed since the Dutch colonialism, and is increasingly fertile after the fall of the New Order regime. The proliferation of radicalism in Indonesia is influenced by the lack of spiritual awareness possessed. As a result the doctrines are easy to enter, one of them is the doctrine of jihad. Furthermore, radicalism is influenced by globalization and education. The effects of this radicalism cause unrest in the community. For this reason, serious efforts are needed in addressing this radicalism, both from the government, scientists and society in general. Therefore, effective management is needed to address radicalism that is flourishing in the community. One of them is the management of spiritual intelligence. The process of building spiritual intelligence management can be done by providing guidance, such as teaching the Koran, practicing prayer, practicing fasting, practicing Hajj and utilizing the method of the Prophet's preaching, namely exemplary approach, maximizing time utilization, fair attitude, praying kindness, activate the potential for thinking and developing mentally. Furthermore in education by providing moral education, which includes habituation, understanding of which good and bad deeds, assignments in which there is reproof, mental cleansing or the soul of all evil and despicable deeds, as well as the obligation to live morally.
\end{abstract}

Key words: Management, Spiritual Intelligence, Radicalism

\section{Pendahuluan}

Manajemen merupakan suatu cabang ilmu yang mempelajari bagaimana mengatur suatu usaha atau memimpin suatu usaha berdasarkan kesepakatan yang telah di tetapkan. ${ }^{1}$ Di dalam manajemen di kenal istilah mengatur yang pelaksanaan melalui proses perencanaan sesuai dengan urutan yang telah di buat untuk mencapai

1 Awaluddin Faj, "Manajemen Pendidikan Pesantren Dalam Perspektif Dr. Kh. Abdullah Syukri Zarkasyi, M.A," At-Ta'dib 6, No. 2 (26 Desember 2011): 240, Https://Doi.Org/10.21111/AtTadib.V6i2.558. hasil yang maksimal. ${ }^{2}$ Sehingga setiap menginginkan suatu keberhasilan dalam setiap usaha apabila dilakukan dengan manajemen yang baik akan mengakibatkan dampak perubahan yang besar terhadap usaha tersebut.

Perubahan yang besar disini adalah perubahan terhadap diri manusia yang bersifat pemahaman yang berasal dari hasil pemikiran manusia terhadap suatu keadaan

2 Nurul Yaqin, "Manajemen Lembaga Pendidikan Islam," Madinab: Jurnal Studi Islam 3, No. 2 (1 Desember 2016): 93. 
atau peristiwa. Untuk mewujudkan perubahan ini diperlukan kecerdasan yang baik yang dimiliki oleh setiap individu. Kecerdasan adalah kemampuan alamiah (fitrah) yang sudah ada di dalam diri manusia. Sebagai anugerah terbesar dari Allah swt dan yang membedakan manusia dengan makhluk yang lain. ${ }^{3}$

Salah satu kecerdasan yang ada di dalam diri manusia adalah kecerdasan spiritual. Kecerdasan spiritual merupakan kecerdasan yang berasal dari dalam hati, membuat manusia menjadi kreatif apabila mereka berhadapan dengan masalah pribadi, dan mencoba menemukan makna yang tersirat didalamnya, serta mencari jalan keluar dengan tenang sehingga mendapatkan kedamaian hati. ${ }^{4}$

Dengan adanya kecerdasan spiritual ini akan membuat seseorang dapat mengenal dan memahami diri nya sepenuhnya sebagai makhluk spiritual maupun sebagai bagian dari alam semesta. ${ }^{5}$ Oleh karenanya, kecerdasan spiritual ini akan membuat seseorang apabila ia bertindak akan memperhitungkan makna dan akibat dari tindakannya tersebut. Untuk itu di masa sekarang ini kecerdasan spiritual sangat di perlukan untuk membentengi diri dari pemikiran-

3 Iin Inayatussalamah, "Kecerdasan Spiritual Dalam Majelis Pesona Ilahi Ponorogo," Cendekia: Jurnal Kependidikan Dan Kemasyarakatan 13, No. 2 (4 April 2016):

Https://Doi.Org/10.21154/Cendekia.V13i2.245.

${ }^{4}$ Inayatussalamah, 190.

5 Idaman Idaman Dan Samsul Hidayat, "AlQur'an Dan Kecerdasan Spiritual: Upaya Menyingkap Rahasia Allah Dalam Al-Qur'an," Khatulistiwa 1, No. 1 (3 Maret 2011): 63, Http://Jurnaliainpontianak.Or.Id/Index.Php/Khatul istiwa/Article/View/181. pemikiran yang ada dimasyarakat yang merusak yang bisa mengakibat perbuatan yang negatif dan merugikan banyak orang. Salah satu pemikiran yang berkembang di masyarakat yaitu paham radikalisme.

Radikalisme adalah suatu paham yang di ciptakan oleh sekelompok orang yang mengharapkan perubahan atau pembaharuan di bidang sosial politik secara signifikan dengan menggunakan tindakantidakan kekerasan. $^{6} \quad$ Di indonesia radikalisme selalu dikaitkan kepada agama, namun apabila dipandang dari sudut keagamaan dapat dijelaskan sebagai paham keagamaan yang mengarah kepada fondasi agama yang paling mendasar dengan fanatisme keagamaan yang begitu besar, sehingga tidak sedikit pengikut dari paham radikalisme menggunakan kekerasan terhadap orang-orang yang berbeda pemahaman untuk mengaktualisasikan paham keagamaan dan dipercayainya agar diakui secara paksa. ${ }^{7}$

Dengan demikian paham radikalisme merupakan masalah yang harus bisa di cari jalan keluarnya agar paham tersebut bisa di bendung, dan tidak menimbulkan dampak negatif bagi diri, orang lain ataupun masyarakat. Oleh karenanya di perlukan perencanan yang tepat untuk membendung paham-paham yang masuk baik keindonesia, kekeluarga, terlebih yang masuk kedalam diri secara pribadi. Untuk itu di perlukan kecerdasan yang besar untuk mengelola setiap pemahaman terutama yang masuk kedalam diri sehingga

${ }^{6}$ Ahmad Asrori, "Radikalisme Di Indonesia: Antara Historisitas Dan Antropisitas," Kalam 9, No. 2 (30 Desember 2015): 257, Https://Doi.Org/10.24042/Klm.V9i2.331.

7 Asrori, 258. 
kita bisa menyaring apakah ini pemahaman yang baik atau pemahaman yang negatif. Kecerdasan yang besar yang perlu dimiliki itu adalah kecerdasan yang berasal dari hati yaitu kecerdasan spiritual. Sehingga sangat penting melakukan perencanan kecerdasan spiritual yang baik agar bisa membentengi diri dari paham-paham yang berasal dari luar terutama paham radikalisme.

\section{Manajemen Kecerdasan Spiritual}

Sebelum kita membahas manajemen kecerdasan spiritual, perlu sedikit di bahas disini apa itu manajamen dan kecerdasan spiritual. Manajemen menurut Stoner adalah suatu kegiatan yang di mulai dari perencanaan,

pengorganisasian, pengarahan dan pengawasan. ${ }^{8}$ Pendapat ini hampir sama dengan yang di kemukakan oleh Terry yang dikutip Aronaga, bahwa manajemen merupakan proses identik yang berasal dari upaya-upaya perencanaan, pengorganisasian, pelaksanaan dan pengendalian yang semuanya itu di pakai baik dalam bidang ilmu pengetahuan ataupun keterampilan dan diikuti secara bergantian untuk menggapai apa yang telah di tetapkan sejak awal. . .

$\begin{array}{lcr}\text { Kemudian } & \text { manajemen } & \text { adalah } \\ \text { kemampuan } & \text { seseorang } & \text { untuk } \\ \text { mempengaruhi } & \text { orang lain atau dirinya } & \text { din } \\ \text { sendiri dan juga merupakan suatu program }\end{array}$

8 Abd Halim Mubin, "Peningkatan Kualitas Pendidikan (Perspektif Manajemen Pendidikan Islam )," Hunafa: Jurnal Studia Islamika 3, No. 4 (15
Desember
2006): Desember 2006):
Https://Doi.Org/10.24239/Jsi.V3i4.282.351-364.

9 Samsidar Samsidar, "Implementasi Manajemen Kepala Sekolah Dalam Penyelenggaraan Pendidikan Islam," Fitrab:Jurnal Kajian Ilmu-Ilmu Keislaman 1, No. 2 (1 Juni 2016): 232, Https://Doi.Org/10.24952/Fitrah.V1i2.316. dari seorang pemimpin dengan mengacu pada hasil yang ingin di capai. ${ }^{10}$ Secara bahasa manajemen memiliki makna kata kerja yang aktif yang bermakna bertanggung jawab, dimana manajemen tidak hanya bertanggung jawab mengatur orang lain tetapi yang lebih penting bertanggung jawab mengatur diri sendiri secara pribadi. ${ }^{11}$ Dengan demikian Abbas menyatakan bahwa manajemen adalah keahlian atau jabatan untuk mengontrol suatu usaha, serta bertanggung jawab terhadap berhasil atau gagalnya dari usaha tersebut. ${ }^{12}$

Selanjutnya kecerdasan spiritual adalah kecerdasan yang berasal dari dalam diri seseorang mengenai cara mengelola hati supaya sanggup memaknai kehidupan, serta yakin bahwa ada kekuatan yang lebih besar diluar kekuatan manusia. Orang yang mempunyai kecerdasan spiritual sanggup melihat setiap kejadian dengan kacamata yang lebih luas dan hikmat, selalu berpikiran positif, sanggup meminimalisirkan masalah, dan yang paling utama selalu menyandarkan perbuatanya kepada perkataan yang tersirat di dalam hatinya, "tuhan ridho atau tidak terhadap perbuatan yang dilakukannya itu". ${ }^{13}$

10 Faj, "Manajemen Pendidikan Pesantren Dalam Perspektif Dr. Kh. Abdullah Syukri Zarkasyi, M.A," 240.

11 Devi Arisanti, "Manajemen Lingkungan Pendidikan Dalam Perspektif Islam," Jurnal Pendidikan Agama Islam Al-Thariqah 1, No. 1 (24 Agustus 2017): 72.

12 Arisanti, 73.

13 Akbar _, "Pengaruh Kecerdasan Spiritual Terhadap Motivasi Kerja Karyawan Pada Pt Advantage Scm Cabang Makassar," Economics Bosowa 3, No. 4 (6 Agustus 2017): 22. 
Kemudian menurut Zakiah Kecerdasan spiritual adalah kesanggupan individu dalam memaknai kehidupan, memaknai nilai, moral dan sikap terhadap sesama makhluk hidup serta bisa membuat dirinya menjadi pribadi yang positif, penuh kedamaian serta bijaksana kepada sesamanya sehingga mampu membuat kehidupannya menjadi lebih baik. ${ }^{14}$ Kecerdasan spiritual seseorang dimaknai sebagai kemampuan pribadinya yang mempunyai keahlian transenden, serta kesadaran yang besar untuk melewati kehidupan dengan menggunakan pengetahuan spiritual untuk mencari jalan keluar tentang permasalahan hidup, dan berbudi luhur. Seseorang yang memiliki kecerdasan spiritual akan baik dalam berinteraksi dengan tuhan, manusia, alam, dan bahkan diri sendiri. ${ }^{15}$

Dengan demikian kecerdasan spiritual adalah dasar kesadaran setiap orang. Kecerdasan spiritual itu menjadikan seseorang mengetahui siapa dirinya sebenarnya dan bagaimana dirinya memberi makna terhadap hidup orang lain untuk selalu berinteraksi agar hidup lebih bermakna. Kecerdasan Spiritual bisa menolong seseorang memperbaiki dan membangun dirinya secara menyeluruh dengan selalu berfikiran baik dalam menanggapi setiap peristiwa yang dialaminya, Serta membuat seseorang mempunyai kemampuan untuk mengetahui

\footnotetext{
14 Rizky Ardewi Laksmi Dan I. Ketut Sujana, "Pengaruh Kecerdasan Intelektual, Kecerdasan Emosional Dan Kecerdasan Spiritual Terhadap Pemahaman Akuntansi," E-Jurnal Akuntansi, 8 November 2017, 1378, Https://Doi.Org/10.24843/Eja.2017.V21.I02.P19.

15 Inayatussalamah, "Kecerdasan Spiritual Dalam Majelis Pesona Ilahi Ponorogo,” 197.
}

yang mana yang termasuk perbuatan baik dan yang mana termasuk perbuatan jahat. ${ }^{16}$

Dari pemaparan tentang manajemen dan kecerdasan spiritual di atas dapat ditarik kesimpulan bahwa manajemen kecerdasan spiritual yaitu:

1. Proses untuk membangun diri menjadi pribadi yang selalu berpikiran positif, penuh kedamaian, serta berpandangan luas dan bijaksana dalam menyikapi setiap peristiwa yang terjadi.

2. Upaya mengarahkan setiap perbuatan yang dilakukan untuk selalu mengikuti kemampuan pribadinya yang mempunyai keahlian transenden, serta kesadaran yang besar untuk melewati kehidupan dengan menggunakan pengetahuan spiritual untuk mencari jalan keluar tentang permasalahan hidup.

3. Suatu sikap bertanggung jawab kepada diri sendiri maupun orang lain dalam mengatur cara berhubungan dengan tuhan, manusia, alam, dan bahkan diri sendiri, untuk menggapai hasil yang baik sesuai dengan apa yang di harapkan sejak awal.

4. Cara pengawasan terhadap diri dalam melakukan suatu tindakan, dimana tindakan tersebut apakah perbuatan yang baik atau perbuatan yang jahat. 


\section{Radikalisme}

Radikalisme berasal dari bahasa Latin radix yang berarti "akar". Radikalisme adalah paham yang menginginkan suatu perubahan dan pengaturan kembali untuk mencapai kemajuan. Dalam pandangan pengetahuan sosial, radikalisme sangat berhubungan terhadap perilaku atau kedudukan yang menginginkan perubahan terhadap status quo dengan cara menghapuskan status quo secara keseluruhan, dan menggantinya dengan sesuatu yang baru yang tidak sama. ${ }^{17}$

Radikalisme secara umum diketahui sebagai pergerakan sosial yang menuju kepada sesuatu yang bersifat menyimpang. Setidaknya pandangan itu yang dipaparkan oleh Lukman Hakim, Wakil Kepala LIPI, di dalam buku "Islam dan Radikalisme di Indonesia" yang di kemukakannya dalam bagian pengantar buku tersebut. Dari pemaparan demikian, maka muncul istilah anti Barat, ekstrem, teroris, dan anti Amerika. ${ }^{18}$

Kemudian secara sederhana radikalisme merupakan gagasan atau perilaku yang ditandai oleh empat macam sekaligus dengan karakteristiknya yaitu: pertama, sikap tidak peduli dan tidak bisa menghargai argumentasi atau kepercayaan orang lain. Kedua, sikap fanatik, yaitu sikap yang menganggap bahwa dirinyalah yang paling benar dan orang lain salah semua. Ketiga, sikap eksklusif, yaitu melakukan

17 Emna Laisa, "Islam Dan Radikalisme," Islamuna: Jurnal Studi Islam 1, No. 1 (2 Januari 2014): 3, Https://Doi.Org/10.19105/Islamuna.V1i1.554.

18 Muhammad Saekan Muchith, "Radikalisme Dalam Dunia Pendidikan," Addin 10, No. 1 (1 Februari 2016): 170, Https://Doi.Org/10.21043/Addin.V10i1.1133. perbuatan yang berbeda dari kebiasaan orang kebanyakan. Keempat, sikap revolusioner, yaitu selalu menggunakan kekuatan fisik untuk mencapai tujuan. ${ }^{19}$

Oleh karenanya, sejalan dengan perubahan dan adanya tanda pergerakan kelompok- kelompok di masyarakat, menyebabkan radikalisme dan terorisme menjadi satu arti, yaitu radikalisme adalah embrio dari munculnya terorisme. Jika mempunyai paham yang radikal, maka berpotensi tinggi untuk melakukan perbuatan teror. Banyak kejadian di Indonesia dimana terorisme dan radikalisme bergabung sehingga membuat masyarakat umum tidak perlu bersusah payah membedakan antara radikalisme dan terorisme. ${ }^{20}$

Dari pemaparan diatas dapat di simpulkan bahwa radikalisme adalah suatu pemahaman yang menginginkan suatu perubahan yang besar terhadap sesuatu, di mana perubahan itu di wujudkan dengan melakukan pergerakan yang bersifat sosial, yang menyebabkan timbulnya perilaku seperti tidak menghargai pendapat orang lain dan tidak peduli terhadap orang lain. Radikalisme menimbulkan pandangan kepada diri seseorang bahwa dialah yang paling benar sedangkan orang lain salah semua.

Dengan demikian di perlukannya upaya-upaya dalam menyikapi paham radikalisme ini yang sekarang merejalela khususnya di indonesia. Dimana paham ini bisa menimbulkan suatu gejolak yang luar

\footnotetext{
${ }^{19}$ Laisa, "Islam Dan Radikalisme," 3.

20 Muchith, "Radikalisme Dalam Dunia Pendidikan," 171.
} 
biasa apabila tidak di bendung. Oleh karenanya diperlukan pengetahuan khusus yang berhubungan dengan pengetahuan yang bersifat spiritual, untuk membenteng hati dan pikiran kita agar kita tidak mudah terjerumus masuk kedalam paham radikalisme.

\section{Radikalisme Di Indonesia}

Radikalisme yang ada di Indonesia tidak lepas dari agama khususnya agama islam. paham radikalisme yang ada di indonesia telah berkembang semenjak masa penjajahan Belanda. Salah satu gerakan pemikiran Salafiyah pertama di Indonesia adalah di Minangkabau. Gerakan ini mulai berjalan seiring dengan timbulnya orang-orang gerakan pemikiran Salafiyah di Timur Tengah antara lain Muhammad Abduh dan Jamaluddin alAfgani, yang pemikirannya di ambil oleh orang Indonesia yang melaksanakan ibadah haji dan kemudian tinggal untuk menuntut ilmu tentang islam. Setelah kembali kekampung halaman, mereka secara individu atau melalui perkumpulannya melakukan gerakan pembaharuan Islam sesuai dengan aliran Salafiyah. Pemikiran Salafiyah ini sangat di junjung tinggi oleh gerakan Wahabi yang di perkasai oleh Muhammad ibn 'Abd al-Wahhab (17031787). Tujuan dari gerakan Wahabi ini yaitu untuk memurnikan ajaran Islam serta meminta kita kembali kepada ajaran alQur'an dan Sunnah Nabi SAW, sebagaimana yang diamalkan oleh sahabatsahabat rasulullah terdahulu. ${ }^{21}$

Timbulnya gerakan radikalisme di Indonesia sangat berkaitan dengan pasca-

${ }^{21}$ Laisa, "Islam Dan Radikalisme," 4-5.
Orde Baru dari perubahan rezim yang semakin terbuka. Kemunculan gerakan radikalisme agama, antara lain Jemaah Islamiyah (JI) ataupun yang tampak jelas seperti Laskar Jihad, Laskar Jundulloh, FPI, MMI, HTI, adalah akibat dari semakin terbukanya politik dan demokrasi karena jatuhnya Orde Baru. Seandainya tidak ada era reformasi, maka kelompok-kelompok garis keras tersebut tidak akan pernah muncul ke permukaan akibat represi politik yang dilakukan oleh rezim berkuasa. ${ }^{22}$ Selain itu menurut Ahmad Rizky, penyebab munculnya radikalisme di Indonesia hampir semuanya terjadi akibat munculnya kesenjangan sosial dan ekonomi yang disebabkan adanya pihak-pihak tertentu yang menguasai akses pada modal dan kedudukan pada saat era pergerakan nasional. ${ }^{23}$

Indonesia merupakan negara yang menganut sistem pemerintahan demokrasi setelah jatuhnya rezim orde baru. Karena kebanyakan kelompok radikal menjunjung tinggi ideologi islamis yang dikampanyekan kepada semua anggota masyarakat untuk merubah sistem demokrasi yang diangap berasal dari Barat. Menurut mereka, sistem pemerintahan demokrasi terlihat tidak mewakili Islam karena agama islam tidak pernah tahu istilah demokrasi. Demokrasi diketahui sebagai hasil pemikiran manusia yang dianggap lebih istimewa dibandingkan dengan agama. Inilah menurut kalangan radikal dilukiskan sebagai "pemberontakan

22 Galih Puji Mulyono Dan Galih Puji Mulyoto, "Radikalisme Agama Di Indonesia (Ditinjau Dari Sudut Pandang Sosiologi Kewarganegaraan)," Citizenship Jurnal Pancasila Dan Kewarganegaraan 5, No. 1 (29 April 2017): 68, Https://Doi.Org/10.25273/Citizenship.V5i1.1212. ${ }_{23}$ Mulyono Dan Mulyoto, 69. 
atas kekuasaan Tuhan" (the revolt against God's sovereignty). Meskipun mereka mendapatkan sesuatu oleh iklim demokrasi di Indonesia, tetapi agenda pergerakannya adalah untuk menjatuhkan demokrasi itu sendiri, baik dengan cara kekerasan ataupun dengan jalan damai, yang dikerjakan secara radikal revolusioner. ${ }^{24}$

Suburnya paham radikalisme ini karena kurangnya pemahaman spiritual yang dimiliki oleh masyarakat. Sehingga doktrindoktrin agama yang di peroleh langsung diterima secara langsung tanpa harus melakukan penalaran terlebih dahulu apakah doktrin tersebut baik atau baruk, salah satunya doktrin agama yaitu jihat fisabilillah yang ada di dalam agama islam. Fakta yang ada di Indonesia, adanya penyimpangan dalam memaknai jihad yang bersumber dari salah pemahaman dan kemudian dimanfaatkan secara negatif oleh sekelompok orang yang mempunyai pemahaman keras mengenai ajaran Islam sehingga mengesahkan kekerasan dalam melaksanakan tindakannya. Ibnu Qayyim memaparkan jika jihad dipandang dari aspek pelaksanaannya terdiri atas tiga bentuk, yaitu jihad mutlaq (perang menghadapi musuh di medan pertempuran), jihad hujjah (dilaksanakan dalam beradu pendapat dengan pemeluk agama lain dengan mengemukakan argumentasi yang kuat) dan jihad 'amm ${ }^{25}$.

Pada tataran global radikalisme sekarang ini, menurut Syamsul Rijal menuju kepada

\footnotetext{
${ }^{24}$ Masdar Hilmy, "Radikalisme Agama Dan Politik Demokrasi Di Indonesia Pasca-Orde Baru," Miqot: Jurnal Ilmu-Ilmu Keislaman 39, No. 2 (5 Desember 2015): 413-14, Https://Doi.Org/10.30821/Miqot.V39i2.33. 25 Laisa , "Islam Dan Radikalisme," 9.
}

agama. Hal ini disebabkan krisis identitas yang berakhir pada reaksi dan resistensi terhadap barat yang memmbesarkan kolonialisasi di dunia muslim dan mulai terbaginhya dunia muslim ke dalam berbagai negara bangsa (nation-state). Inti dari radikalisme adalah menginginkan terciptanya perubahan terhadap suatu pemerintahan di masyarakat. Tujuan dari radikalisme adalah kedudukan dan mengambil alih politik dengan berpedoman atau memanfaatkan golongan, kumpulankumpulan primordial (suku, bangsa, ras, keyakinan, keagamaan, dan kepercayaan). ${ }^{26}$

Radikalisme tumbuh subur di indonesia juga disebabkan minimnya jenjang pendidikan. Sehingga akibat dari minimnya pendidikan yang diperoleh masyarakat mengakibatkan sedikit informasi pengetahuan yang didapat, ditambah dengan pemahaman agama yang kurang mengakibatkan seseorang dengan gampangnya menerima informasi keagamaan dari orang yang dianggap tinggi keilmuannya tanpa dipahami dulu apakah informasi itu benar atau salah, akibatnya dari hal ini akan menjadi bumerang jika informasi didapat dari orang yang salah.

\footnotetext{
${ }_{26}$ Mulyono Dan Mulyoto, "Radikalisme Agama Di Indonesia (Ditinjau Dari Sudut Pandang Sosiologi Kewarganegaraan)," 5-6.
} 


\section{Manajemen Kecerdasan Spiritual Dalam Menyikapi Paham Radikalisme Di Indonesia}

Radikalisme merupakan tanggapan terhadap keadaan yang sedang terjadi. Tanggapan itu muncul berupa evaluasi, pembangkangan, atau bahkan pertikaian. Oleh karenanya diperlukan suatu proses untuk membangun pribadi secara lebih baik yang selalu berpikiran positif, menanamkan rasa cinta damai, dan menerima suatu keadaan dengan cara berpikir luas dan bijaksana dalam menanggapi suatu permasalahan. Salah satu yang bisa di tawarkan dalam menyikapi paham radikalisme yaitu kecerdasan berpikir secara spiritual dalam menyikapi suatu keadaan tersebut.

Kecerdasan spiritual merupakan kecerdasan dalam menyikapi permasalahan makna, yaitu kecerdasan untuk meletakkan sikap dan pebuatan kita dalam konteks makna yang lebih besar dan mewah, kecerdasan untuk menilai apakah sikap atau perbuatan seseorang lebih berarti apabila disandingkan dengan yang lain. ${ }^{27}$ Dengan adanya Kecerdasan spiritual di dalam diri, maka akan mudah membagikan keindahan, kebaikan, kebenaran, serta kasih sayang dalam pergaulan sehari-hari baik itu di keluarga, organisasi dan didalam lingkungan masyarakat pada umumnya. Kecerdasan spiritual juga bisa membuat orang yang memilikinya bersikap fleksibel yang merupakan suatu sikap yang wajib ada pada diri seseorang dimana sikap ini merupakan sikap tetap tenang dalam

27 Akbar _, "Pengaruh Kecerdasan Spiritual Terhadap Motivasi Kerja Karyawan Pada Pt Advantage Scm Cabang Makassar,” 22. menyikapi setiap peristiwa segenting apapun, dan tanpa kehilangan kontrol. ${ }^{28}$

Untuk itu di perlukan proses untuk membangun kecerdasan spiritual dalam menyikapi paham-paham yang merebak dimasyarakat terutama paham radikalisme ini, dimana proses membangun kecerdasan spiritual ini bisa dilakukan dengan cara memberikan bimbingan, pengarahan, pendidikan secara tepat dalam upaya membentuk kepribadian, perkembangan intelektual, emosional dan spiritual anak. ${ }^{29}$ Dalam memberikan bimbingan bisa kita lakukan dengan cara mengajarkan alqur'an, melatih pelaksanaan shalat, melatih berpuasa, melatih pelaksanaan haji dan memanfaatkan metode dakwah rasulullah s.a.w yaitu metode pendekatan keteladanan, memaksimalkan pemanfaatan waktu, sikap adil, mendoakan kebaikan, mengaktifkan potensi berpikir dan mengembangkan mental. $^{30}$

Selanjutnya dengan memberikan pendidikan yang tepat, pendidikan yang sangat erat sekali dengan kecerdasan spiritual adalah pendidikan agama yang berhubungan dengan pendidikan akhlak. Agama adalah referensi akhlak yang tidak akan habis, karena agama melihat dan mengontrol semua perbuatan manusia. Jadi mempelajari akhlak adalah sangat penting untuk semua manusia yang beragama, rasanya agama apapun setuju dan beranggapan sama bahwa pengikutnya haruslah berperilaku baik dan menjauhi

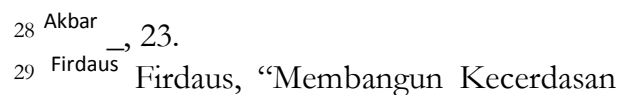
Spiritual Islami Anak Sejak Dini," Al-Adyan 10, No. 1 (24 Agustus 2017): 103.

${ }^{30}$ Firdaus, 107. 
perbuatan jahat, seperti yang di anjurkan di dalam agama tersebut. Nilai akhlak tidak akan terlihat kecuali dahulunya sudah pernah dipelajari karakteristiknya mengenai hakikat pendidikan akhlak itu sendiri. Pengertian hakikat pendidikan akhlak mempunyai berbagai pandangan. Kelompok pertama menyatakan bahwa pendidikan akhlak adalah berhubungan dengan pengulangan atau pembiasaan. Keutamaan akhlak tampak secara khusus karena kebiasaan dan perilaku. pendeknya kelompok ini mengungkapkan bahwa pendidikan akhlak adalah dengan pengulangan yang berkelanjutan untuk melakukan suatu tindakan. Pendapat kedua yaitu menyatakan bahwa pendidikan bisa membentuk akhlak seseorang, mampu memilih mana jalan yang baik dan buruk. Kelompok ketiga mengatakan bahwa pendidikan akhlak berlanjut dengan penugasan-penugasan, yang didalamnya terdapat kalimat teguran. Kelompok keempat menyatakan bahwa pendidikan akhlak bukan hanya berbicara mengenai perilaku yang tampak dengan kasat mata, namun juga berbicara mengenai pembersihan bathin atau jiwa dari semua perbuatan yang jahat dan hina, bahkan memperindah dengan semua sisi keutamaan secara lahir dan batin. Dan kelompok terakhir menyatakan bahwa pendidikan akhlak adalah pendidikan yang menciptakan kesanggupan sikap berakhlak. ${ }^{31}$

Dalam proses pembentukan dan pengembangan kecerdasan spiritual adalah kita tidak terlepas dari faktor apa saja yang mempengaruhinya. Ada dua faktor penting

\footnotetext{
31 Firdaus, 109.
}

yang mempengaruhi inteligensi seseorang, yaitu faktor bawaan dan faktor lingkungan ${ }^{32}$. faktor bawaan ini adalah faktor yang sudah ada sejak manusia lahir kedunia sebagaimana yang di tegaskan dalam hadits nabi yang menyatakan "setiap anak dilahirkan dalam keadaan fitrah". Para pakar hadits menafsirkan kata "fitrah" sebagai potensi bertuhan atau beragama. ${ }^{33}$ Sedangkan faktor lingkungan adalah faktor yang berasal dari luar diri manusia, seperti pendidikan yang di berikan dalam lingkungan keluarga. Keluarga merupakan pendidikan pertama bagi seseorang dalam pembentukan serta pengembangan jiwa keagamaan dan kecerdasan spiritual anak. Keluarga merupakan lingkungan utama sebab seorang anak yang lahir pertamatama mendapat bimbingan dan didikan adalah dari keluarga dan Sebagian besar kehidupannya di habiskan di lingkungan keluarga ${ }^{34}$.

\section{Penutup}

Dari pemaparan diatas dapat disimpulkan bahwa paham radikalisme yang ada diindonesia bisa debendung dengan cara membentuk manajemen kecerdasan spiritual yang baik. manajemen kecerdasan spiritual yang dimulai dari memberikan bimbingan, pendidikan dan melakukan dakwah dengan cara metodenya rasulullah s.a.w. bimbingan yang dimaksud adalah dengan cara mengajarkan al-qur'an, melatih

\section{Firdaus, 105.}

33 Lailatul Maghfiroh, "Membangun Karakter Siswa Dan Meningkatkan Kecerdasan Spiritual Melalui The Hidden Curriculum Di Mi Wahid Hasyim Yogyakarta," Dar El-Ilmi: Jurnal Studi Keagamaan, Pendidikan, Dan Humaniora 4, No. 1 (6 Oktober 2017): 2015.
34 Firdaus, Spiritual Islami Anak Sejak Dini,’ 105. 
pelaksanaan shalat, melatih berpuasa, dan melatih pelaksanaan haji. Untuk pendidikan kita mulai dengan memberikan pendidikan agama yang berhubungan dengan akhlak yang isinya berupa pembiasaan, memberikan pandangan tentang mana yang benar dan yang salah, melakukan penugasan-penugaan yang berisi teguran, pembersihan bathin atau jiwa dari semua perbuatan yang jahat dan hina, dan menciptakan kesiapan untuk hidup berakhlak. Selanjutnya melakukan dakwah dengan cara metodenya rasulullah s.a.w. yaitu metode pendekatan keteladanan, memaksimalkan pemanfaatan waktu, sikap adil, mendoakan kebaikan, mengaktifkan potensi berpikir dan mengembangkan mental. Sehingga apabila kita melakukan manajemen spiritual yang baik akan bisa membentengi kita dari segala pahampaham yang bersifat negatif.

\section{Daftar Pustaka}

Akbar _. "Pengaruh Kecerdasan Spiritual Terhadap Motivasi Kerja Karyawan Pada Pt Advantage Scm Cabang Makassar." Economics Bosowa 3, No. 4 (6 Agustus 2017): 17-31.

Arisanti, Devi. "Manajemen Lingkungan Pendidikan Dalam Perspektif Islam." Jurnal Pendidikan Agama Islam Al-Thariqah 1, No. 1 (24 Agustus 2017): 71-86.

Asrori, Ahmad. "Radikalisme Di Indonesia: Antara Historisitas Dan Antropisitas." Kalam 9, No. 2 (30 Desember 2015): 253-68. Https://Doi.Org/10.24042/Klm. V9i2.331.

Faj, Awaluddin. "Manajemen Pendidikan Pesantren Dalam Perspektif Dr.
Kh. Abdullah Syukri Zarkasyi, M.A." At-Ta'dib 6, No. 2 (26 Desember 2011). Https://Doi.Org/10.21111/AtTadib.V6i2.558.

Firdaus, Firdaus. "Membangun Kecerdasan Spiritual Islami Anak Sejak Dini." Al-Adyan 10, No. 1 (24 Agustus 2017): 99-122.

Hilmy, Masdar. "Radikalisme Agama Dan Politik Demokrasi Di Indonesia Pasca-Orde Baru." Miqot: Jurnal Ilmu-Ilmu Keislaman 39, No. 2 (5 Desember 2015). Https://Doi.Org/10.30821/Miqot. V39i2.33.

Idaman, Idaman, Dan Samsul Hidayat. "Al-Qur'an Dan Kecerdasan Spiritual: Upaya Menyingkap Rahasia Allah Dalam Al-Qur'an.” Khatulistiwa 1, No. 1 (3 Maret 2011). Http://Jurnaliainpontianak.Or.Id/ Index.Php/Khatulistiwa/Article/V iew/181.

Inayatussalamah, Iin. "Kecerdasan Spiritual Dalam Majelis Pesona Ilahi Ponorogo." Cendekia: Jurnal Kependidikan Dan Kemasyarakatan 13, No. 2 (4 April 2016): 189-206. Https://Doi.Org/10.21154/Cende kia.V13i2.245.

Laisa, Emna. "Islam Dan Radikalisme." Islamuna: Jurnal Studi Islam 1, No. 1 (2 Januari 2014). Https://Doi.Org/10.19105/Islam una.V1i1.554.

Laksmi, Rizky Ardewi, Dan I. Ketut Sujana. "Pengaruh Kecerdasan Intelektual, Kecerdasan Emosional Dan Kecerdasan Spiritual Terhadap Pemahaman Akuntansi." 
E-Jurnal Akuntansi, 8 November 2017, 1373-99.

Https://Doi.Org/10.24843/Eja.20 17.V21.I02.P19.

Maghfiroh, Lailatul. "Membangun Karakter Siswa Dan Meningkatkan Kecerdasan Spiritual Melalui The Hidden Curriculum Di Mi Wahid Hasyim Yogyakarta." Dar El-Ilmi: Jurnal Studi Keagamaan, Pendidikan, Dan Humaniora 4, No. 1 (6 Oktober 2017): 201-18.

Mubin, Abd Halim. "Peningkatan Kualitas

Pendidikan (Perspektif Manajemen

Pendidikan Islam )." Hunafa: Jurnal

Studia Islamika 3, No. 4 (15

Desember 2006): 351-64.

Https://Doi.Org/10.24239/Jsi.V3i 4.282.351-364.

Muchith, Muhammad Saekan.

"Radikalisme Dalam Dunia

Pendidikan." Addin 10, No. 1 (1

Februari 2016): 163-80.

Https://Doi.Org/10.21043/Addin

.V10i1.1133.

Mulyono, Galih Puji, Dan Galih Puji Mulyoto. "Radikalisme Agama Di Indonesia (Ditinjau Dari Sudut Pandang Sosiologi Kewarganegaraan).” Citizenship Jurnal Pancasila Dan Kewarganegaraan 5, No. 1 (29 April 2017): 64-74. Https://Doi.Org/10.25273/Citize nship.V5i1.1212.

Samsidar, Samsidar. "Implementasi Manajemen Kepala Sekolah Dalam Penyelenggaraan Pendidikan Islam.” Fitrah:Jurnal Kajian Ilmu-Ilmu Keislaman 1, No. 2 (1 Juni 2016): 229-44.
Https://Doi.Org/10.24952/Fitrah. V1i2.316.

Yaqin, Nurul. "Manajemen Lembaga Pendidikan Islam." Madinab: Jurnal Studi Islam 3, No. 2 (1 Desember 2016): $93-105-93-105$. 